\title{
Peningkatan sadar lingkungan melalui penghematan sampah plastik
}

\section{Firdha Aksari Anindyntha ${ }^{1 *}$, Dwi Susilowati ${ }^{2}$, Setyo Wahyu Sulistyono ${ }^{3}$}

\author{
${ }^{1}$ Universitas Muhammadiyah Malang, Indonesia, email: firdhaaksari@umm.ac.id \\ 2Universitas Muhammadiyah Malang, Indonesia, email:dwi_s@umm.ac.id \\ 3Universitas Muhammadiyah Malang, email: setyowahyu88@umm.ac.id \\ *Koresponden penulis
}

\section{Info Artikel}

Diajukan: 18 Feb 2021

Diterima: 14 Agst 2021

Diterbitkan: 21 Agst 2021

Keywords:

plastic waste; saving; environmentally conscious

Kata Kunci:

sampah plastik; hemat; sadar lingkungan

Lisensi:

cc-by-sa

\begin{abstract}
Plastic waste is difficult to decompose, so it causes environmental problems. The amount of environmental pollution by plastic waste in Indonesia is due to the lack of balance between the volume of waste and its handling efforts. The increasing volume of plastic waste has an impact on the severity of waste processing in Integrated Waste Disposal Sites. The community service team in collaboration with Mulyoagung Village Head held a community service program to change people's habits from passive about waste to active through waste saving education. There are three activities in this program, namely educate the public to reduce household waste especially plastic, carry out a campaign to save plastic waste by making and installing posters or billboards in strategic places, and encourage the Mulyoagung Village apparatus to initiate the use of tumbler. The result of this activity is the high participation of the community as seen from attendance of participants and enthusiasm of participants to ask questions, installation of posters and billboards, also used of tumblers to village office every day. To make this activity can be continuity and sustainable, the community service team will do community service program in the same place with the theme of environmental problems.
\end{abstract}

\section{Abstrak}

Sampah plastik merupakan sampah yang sulit diurai, sehingga menimbulkan masalah lingkungan. Banyaknya pencemaran lingkungan oleh sampah plastik di Indonesia disebabkan kurang seimbangnya antara volume sampah dengan usaha penanganannya, maka diperlukan penanganan supaya diorganisir lebih baik. Volume sampah plastik yang terus meningkat akan berdampak pada semakin beratnya pengolahan sampah di TPST (Tempat Pembuangan Akhir Sampah). Berdasarkan kondisi tersebut, tim pengabdi bekerjasama dengan Kepala Desa Mulyoagung mengadakan program pengabdian masyarakat. Program ini berusaha mengubah kebiasaan masyarakat yang pasif terhadap sampah menjadi aktif melalui edukasi hemat sampah. Langkah pertama adalah mengedukasi masyarakat tentang perlunya mengurangi sampah rumah tangga khususnya plastik melalui penyuluhan kader di Desa Mulyoagung. Kedua melakukan kampanye hemat sampah plastik melalui kegiatan promosi dengan pembuatan dan pemasangan poster atau baliho di tempat strategis. Ketiga mendorong perangkat Desa Mulyoagung untuk menginisasi pemakaian tumbler. Hasil kegiatan pengabdian ini adalah tingginya partisipasi masyarakat untuk mengikuti edukasi bahaya sampah sebagaimana dilihat dari tingkat kehadiran peserta yang sesuai 
dengan target dan antusias peserta untuk bertanya, terpasangnya poster dan baliho di kantor Desa, serta penggunaan tumbler ke kantor desa setiap hari Rencana selanjutnya agar kegiatan ini dapat berlangsung dan berkesinambungan, maka tim pengabdi sepakat melakukan pengabdian di tempat yang sama dengan tema masalah lingkungan.

\section{PENDAHULUAN}

Bentuk kesadaran masyarakat akan bahaya sampah plastik perlu penegasan yang lebih mendalam mengingat jumlah sampah plastik yang semakin meningkat karena plastik banyak digunakan dalam kehidupan seharihari masyarakat. Sejak krisis ekonomi global berakhir di tahun 2010, emisi plastik banyak ditimbulkan oleh industri-industri besar karena produksi plastik meningkat (Dobrovszky, 2018). Plastik memiliki harga yang murah, ringan sehingga mudah dibawa, tidak mudah lapuk dan anti karat (Septiani et al., 2019; Thompson et al., 2009). Purwaningrum (2016) menyebutkan bahwa 60-70\% komposisi sampah dari aktivitas manusia adalah sampah organik dan sisanya sampah non organik sebesar $30-40 \%$, dimana sebesar $14 \%$ dari komposisi sampah non organik merupakan sampah plastik. Plastik sendiri merupakan bagian yang penting dalam ekonomi secara global karena memadukan sifat fungsional dengan biaya yang kompetitif. Namun, di sisi lain plastik juga memiliki kekurangan karena berdampak terhadap lingkungan (Garofalo et al., 2018).

Sampah di Indonesia meningkat sebesar 38 juta ton per tahun dan $30 \%$ dari sampah tersebut adalah sampah plastik (Hendiarti, 2018). Pola konsumsi masyarakat turut serta berkontribusi dalam peningkatan volume sampah dengan jenis beragam, dimana sampah rumah tangga menjadi salah satu sumber sampah yang cukup besar peranannya dalam peningkatan volume sampah di suatu lingkungan (Sari et al., 2018). Jika peningkatan volume sampah terus terjadi terutama yang bersumber dari sampah rumah tangga, maka dapat berpotensi mencemari lingkungan. Dengan demikian, untuk mengurangi masalah sampah perlu pengelolaan sampah secara mandiri sejak di tingkat rumah tangga (Restuningdiah et al., 2021).

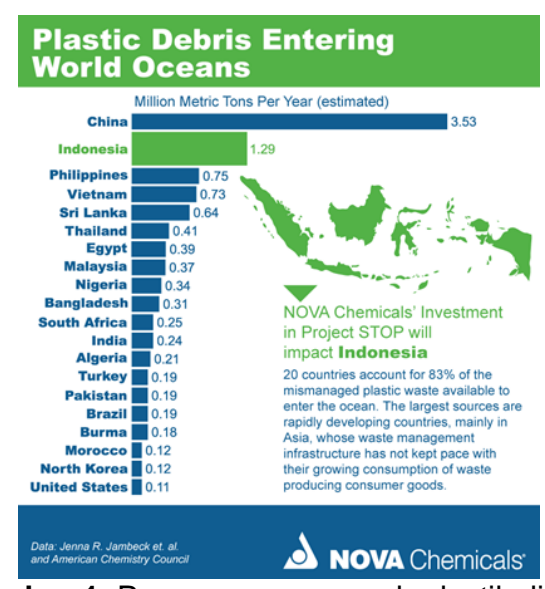

Gambar 1. Pencemaran sampah plastik di laut 
Negara-negara di Asia Tenggara diidentifikasi sebagai sumber utama pencemaran sampah plastik di laut karena perkembangan ekonomi dan konsumsi plastik telah melampaui perluasan sistem pengelolaan limbah di wilayahnya. Pada gambar 1 menunjukkan bahwa Indonesia menempati urutan kedua konsumsi sampah plastik setelah Cina dengan nilai pencemaran pada lautan atas penggunaan dari sisi permintaan dan penawaran pada konsumsi sampah plastik sebesar 1,29 juta metrik ton per tahun (Borealis, 2018).

Apakah Indonesia begitu abai dalam menangani sampah terutama limbah plastik? Sebenarnya tidak juga karena banyak pihak dengan latar belakang beragam ilmu dan profesi sudah berusaha untuk melakukan itu. Contohnya dr. Gamal Abinsaid yang berinovasi mendirikan klinik dengan bayaran berupa sampah baik plastik maupun non plastik. Ide tersebut muncul karena peduli dengan masalah lingkungan dan sosial dimana sebagai seorang dokter prihatin melihat banyak orang sakit yang tidak mampu berobat karena ada kendala pada biaya (Oktavia, 2019).

Sebagian besar penanganan sampah yang mereka lakukan berupa tindakan pengumpulan dan mendaur ulang sampah plastik yang dihasilkan oleh masyarakat. Artinya mereka melakukan penanganan sampah setelah sampah tersebut sudah terbentuk atau dengan kata lain penangan sampah terjadi di arah hilir. Sangat sedikit yang melakukan penanganan sampah plastik dari arah hulu, yaitu mencegah terbentuknya sampah plastik itu sendiri dengan cara mengurangi penggunaan produk plastik atau produk yang mengandung bahan baku plastik. Mencegah atau mengurangi penggunaan produk plastik atau produk yang mengandung bahan baku plastik jauh lebih sulit karena menyangkut perubahan perilaku masyarakat. Merubah perilaku masyarakat tidak dapat dilakukan dalam jangka waktu yang singkat karena berhubungan dengan perubahan kebiasaan. Usaha mengubah perilaku harus dilakukan secara konsisten terus menerus tanpa jeda sama sekali, sehingga memerlukan sumber daya yang besar. Oleh karena itu, jarang yang mau untuk melakukannya.

Pemerintah Pusat pernah berusaha melakukan untuk mengubah kebiasaan masyarakat yaitu dengan mengenakan tarif bagi konsumen retail untuk setiap kantong plastik yang digunakan untuk membawa produk yang dibelinya di toko retail dengan dasar Surat Edaran (SE) Menteri Lingkungan Hidup dan Kehutanan Nomor S.71/Men LHK - II/ 2015 tentang pembatasan pemberian kantong plastik (Lupiyanto, 2020). Namun usaha itu dihentikan karena ternyata kebijakan tersebut tidak efektif. Dalam arti belum bisa merubah perilaku konsumen dalam berbelanja karena konsumen tetap memilih kantong plastik yang disediakan retail dibanding membawa sendiri kantong belanjaan. Bisa jadi hal ini disebabkan oleh tarif kantong plastik yang masih terlalu murah, yaitu hanya Rp. 2.000/kantong plastik, disamping kebijakan tersebut bersifat hukuman bukan reward. Mungkin hasilnya akan berbeda bila sifatnya reward, artinya yang membawa kantong sendiri diberi hadiah berupa potongan penjualan sebesar tarif kantong plastik yang semestinya harus dibayar oleh konsumen. Purwoko (2012) dalam penelitiannya merekomendasikan pada pemerintah untuk mengenakan cukai bertarif tinggi terhadap kantong plastik 
supaya dapat menurunkan permintaan kantong plastik tanpa harus mengurangi Produk Domestik Bruto (PDB).

Pada kasus kantong plastik pemerintah berupaya merubah perilaku masyarakat yang berperan sebagai konsumen, namun Pemerintah Pusat belum pernah berupaya menekan penggunaan produk plastik dengan cara mengubah perilaku masyarakat yang berperan sebagai produsen (Lathif, 2019). Pihak yang pernah melakukan hanya Pemerintah Kota Bandung, yaitu berupa aturan pelarangan penggunaan styrofoam untuk bungkus makanan dan minuman (Utomo, 2016). Larangan ini dilakukan karena Pemkot Bandung menemukan bahwa sebagian besar sampah yang ada di gorong-gorong Kota Bandung adalah plastik dan styrofoam. Jika hanya mengandalkan upaya dari pemerintah, baik pusat maupun daerah, maka bisa dipastikan bahwa upaya mengurangi limbah plastik melalui perubahan perilaku konsumen dan produsen akan menemui jalan buntu atau kegagalan. Usaha ini perlu dukungan dan secara nyata dari seluruh lapisan masyarakat dan dari segenap golongan masyarakat termasuk didalamnya kaum akademisi.

Desa Mulyoagung Kecamatan Dau Kabupaten Malang merupakan salah satu yang menghadapi masalah sampah khususnya sampah plastik. Desa Mulyoagung terdiri dari 5 Dusun, yaitu Dusun Jetis, Jetak Lor, Sengkaling, Dermo dan Jetak Ngasri. Data dari Tempat Pengolahan Sampah Terpadu (TPST) Mulyoagung menunjukkan bahwa sampah plastik mengalami peningkatan per bulannya, yaitu rata-rata volume 28 ton perbulan dengan 13 ton merupakan sampah plastik. Sampah sejumlah tersebut merupakan sampah yang dihasilkan dari 1.200 KK 72 RT (TPST Mulyoagung Bersatu, 2020).

Pengabdian dengan mengambil permasalahan sampah plastik akan dilakukan di Dusun Sengkaling. Pemilihan lokasi ini dengan pertimbangan bahwa Dusun Sengkaling merupakan dusun yang ramai karena terdapat banyak tempat umum, seperti aneka kuliner, hotel, pertokoan, tempat wisata, dan perkantoran yang terletak di jalan Raya Sengkaling. Tempat-tempat tersebut merupakan tempat yang rawan terdapat sampah khususnya sampah plastik. Model pengabdian lebih banyak ditekankan kepada edukasi dan pendampingan bagaimana berhemat dalam penggunaan sampah plastik.

Tujuan program pengabdian masyarakat adalah munculnya kesadaran masyarakat akan bahaya sampah plastik, sehingga diperlukan peran masyarakat untuk mengubah kebiasan atau perilaku supaya dalam jangka panjang dapat mengurangi volume sampah plastik. Merubah perilaku masyarakat adalah hal yang sulit, tetapi jika dilakukan secara terus menerus akan mendapat hasilnya (Riswan et al., 2015). Secara lebih rinci tujuan yang ingin dicapai dari kegiatan pengabdian masyarakat ini adalah peningkatkan sadar lingkungan melalui kegiatan pemberian informasi berupa edukasi dan penyuluhan terkait bahaya sampah plastik yang dimulai dari perangkat Desa kemudian diikuti masyarakat Desa Mulyoagung Kecamatan Dau Kabupaten Malang serta kesadaran untuk menggunakan produk yang ramah lingkungan dalam kegiatan sehari-hari seperti penggunaan tumbler sebagai pengganti air minum kemasan. 


\section{METODE PELAKSANAAN}

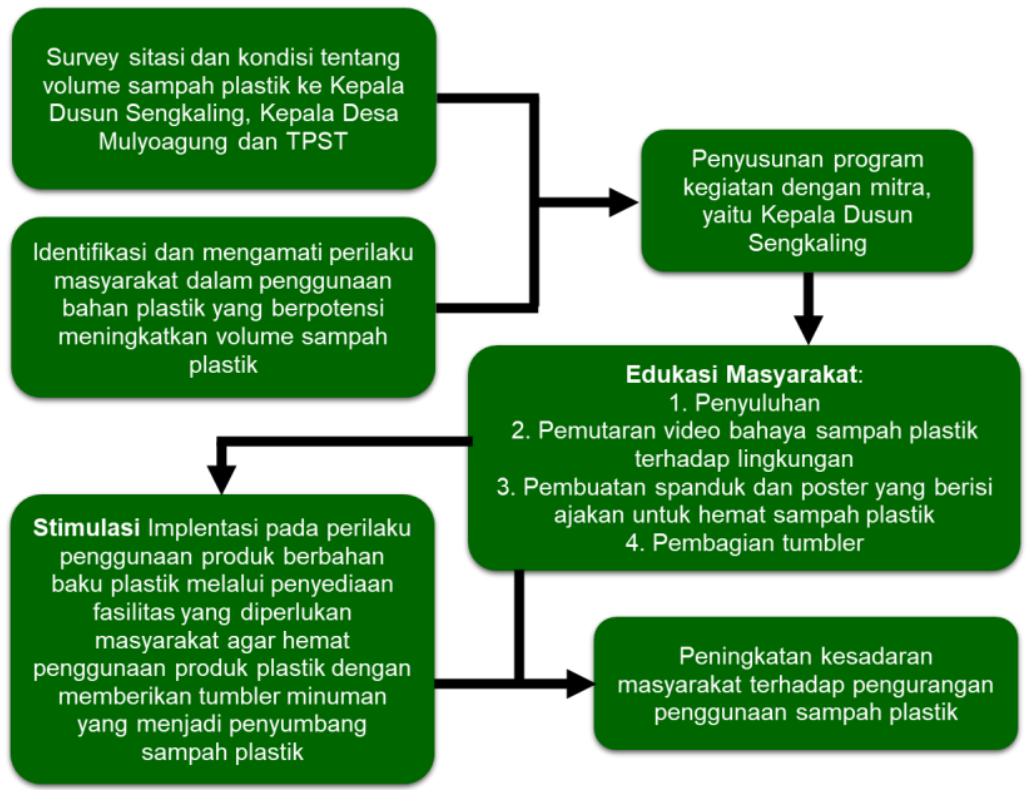

Gambar 2. Rancangan program pengabdian

Pada gambar 2 terlihat rancangan program pengabdian masyarakat yang akan dilakukan mulai dari survey awal, penyusunan program bersama mitra, hingga metode pelaksanaannya. Program pengabdian masyarakat ini dilakukan dengan tiga rangkaian kegiatan, meliputi: (1) edukasi dan penyuluhan ke masyarakat, (2) pembuatan baliho dan poster, serta (3) pemberian tumbler ke masyarakat. Kegiatan pertama adalah tim pengabdi melakukan edukasi dan memberi penyuluhan untuk perangkat Desa dan warga masyarakat di Desa Mulyoagung Kecamatan Dau Kabupaten Malang melalui power point dan pemutaran video tentang bahaya sampah plastik bagi lingkungan dan kesehatan. Selanjutnya dilakukan dialog interaktif dengan para peserta penyuluhan supaya dapat memberikan pemahaman yang lebih mendalam.

Kegiatan kedua adalah pembuatan baliho dan poster oleh tim pengabdi yang berisi himbauan pengurangan penggunaan produk berbahan baku plastik sebagai bentuk kampanye untuk hemat sampah plastik. Baliho dan poster yang telah dibuat akan dipasang di beberapa tempat strategis, salah satunya di kantor Desa Mulyoagung supaya mudah dilihat dan dibaca oleh masyarakat. Terakhir adalah dengan memberikan tumbler bagi masyarakat, kepala Desa beserta perangkat Desa Mulyoagung Kecamatan Dau Kabupaten Malang sebagai langkah kongkrit untuk mengurangi penggunaan sampah plastik.

Pengendalian program pengabdian dilakukan melalui kegiatan monitoring, pengawasan, evaluasi dan pelaporan terhadap pelaksanaan kegiatan serta tindak lanjut pembinaan yang akan dilakukan terhadap mitra. Pengendalian terhadap seluruh proses dan kegiatan pendampingan ditujukan untuk dapat memastikan bahwa seluruh tahapan kegiatan sesuai dengan 
proses dan mekanisme yang telah ditetapkan. Selanjutnya adalah mengendalikan kegiatan agar sesuai dengan rencana yang telah ditetapkan serta dapat menjaga kualitas kegiatan agar sesuai dengan program kerja.

\section{HASIL DAN PEMBAHASAN}

Program pengabdian masyarakat tentang pendampingan peningkatan sadar lingkungan melalui penghematan sampah plastik di lingkungan rumah tangga di Desa Mulyoagung Kecamatan Dau Kabupaten Malang. Desa Mulyoagung terdiri dari 5 Dusun, yaitu Dusun Sengkaling, Dusun Jetak Lor, Dusun Jetis, Dusun Jetak Ngasri, dan Dusun Dermo.

Desa Mulyoagung sudah memiliki Tempat Pembuangan Sampah Terakhir atau yang dikenal dengan istilah TPST $3 R$ yang terletak di Dusun Dermo. TPST 3R (Reduce, Reuse, dan Recycle) Mulyoagung merupakan suatu upaya pengendalian dan pengelolaan sampah terpadu oleh Pemerintah dan Masyarakat Desa Mulyoagung, Kecamatan Dau Kabupaten Malang demi terwujudnya kualitas hidup yang bersih, sehat, dan nyaman. Keberadaan TPST di Desa Mulyoagung sejalan dengan studi oleh (Sudibyo et al., 2017) yang menggunakan dua metode untuk mengurangi sampah, yaitu TPST beroperasi tanpa pengurangan sampah atau melakukan daur ulang dan pengomposan serta TPST beroperasi dengan mengurangi sampah dari sumbernya dikombinasikan dengan pengurangan di TPST itu sendiri.

Pengangkutan sampah di TPST dengan menggunakan tiga jenis kendaraan yaitu gerobak, becak motor, dan kendaraan pick up dengan volume sampah yang dapat dilihat dalam tabel sebagai berikut:

Tabel 1. Rata-rata volume sampah (m3/hari)

\begin{tabular}{clc}
\hline No. & Jenis Kendarann & Volume \\
\hline 1. & Gerobak & 0,82 \\
2. & Becak Motor & 2,63 \\
3. & Pick Up & 4,3 \\
\hline
\end{tabular}

\section{Gerakan Sadar Lingkungan dengan Metode Pemberian Informasi Berupa Edukasi dan Penyuluhan}

Masyarakat perlu dididik dan diberi informasi mengenai permasalahan lingkungan dalam rangka menghadapi tantangan permasalahan lingkungan di bumi (Desfandi, 2015). Setelah masyarakat memahami tentang permasalahan lingkungan, selanjutnya masyarakat diedukasi dengan melakukan sosialisasi untuk dapat meningkatkan sadar lingkungan. Sampah yang tidak terkendali merupakan salah satu penyumbang masalah lingkungan yang berkaitan dengan iklim. Sampah berpotensi menyumbang dalam peningkatan emisi gas rumah kaca sebagai akibat dari penumpukan sampah tanpa diolah yang dapat melepaskan gas methane $\left(\mathrm{CH}_{4}\right)$ (Karmanah, Wibaningwati \& Rusli, 2016).

Langkah awal dalam melakukan sosialisasi bahaya sampah plastik ditujukan terlebih dahalu ke perangkat Desa. Perangkat Desa yang terdiri dari kepala Desa Mulyoagung beserta staf setuju untuk diberikan edukasi 
dan penyuluhan terlebih dahulu. Dengan demikian telah disepakati bahwa edukasi dan penyuluhan bahaya sampah plastik akan dilaksanakan pada hari Selasa tanggal 10 September 2020. Adapun kegiatan dimulai pada pukul 12.00 sampai dengan pukul 12.30 diawali dengan pemutaran video tentang bahaya sampah plastik. Dilanjutkan ishoma sampai dengan pukul 13.00. Pukul 13.00 - 15.00 acara inti dimulai yaitu penyuluhan tentang "Gerakan Sadar Lingkungan Melalui Penghematan Sampah Plastik" bertempat di kantor Desa Mulyoagung. Kegiatan edukasi dan penyuluhan diikuti sejumlah 25 peserta yang terdiri dari perangkat desa beserta dengan PKK Desa. Sebelum acara penutupan dilakukan pembagian tumbler secara simbolis diwakili oleh bapak Kepala Desa setelah itu dibagikan ke semua peserta.

Edukasi dan penyuluhan bahaya sampah plastik disampaikan dalam bentuk penjelasan melalui tatap muka dengan menggunakan power point dan penayangan video tentang bahaya sampah plastik yang selanjutnya dilakukan sesi tanya jawab serta diskusi. Sebagian besar peserta belum memahami akan bahaya yang serius dari sampah plastik, sehingga dengan diberi penjelasan dari tim pengabdi banyak yang terkejut dan banyak yang bertanya. Sebagian besar pertanyaan berkisar bagaiama cara mengurangi sampah plastik yang bisa dilakukan sendiri karena sampah plastik terutama kantong plastik banyak ditemui sehari-hari dan sangat mudah diperoleh. Selain itu, para peserta tertarik untuk mengolah sampah plastik menjadi barang yang mempunyai nilai tambah secara ekonomis. Para peserta juga meminta untuk diajarkan cara mengolah sampah plastik terutama sampah plastik rumah tangga.

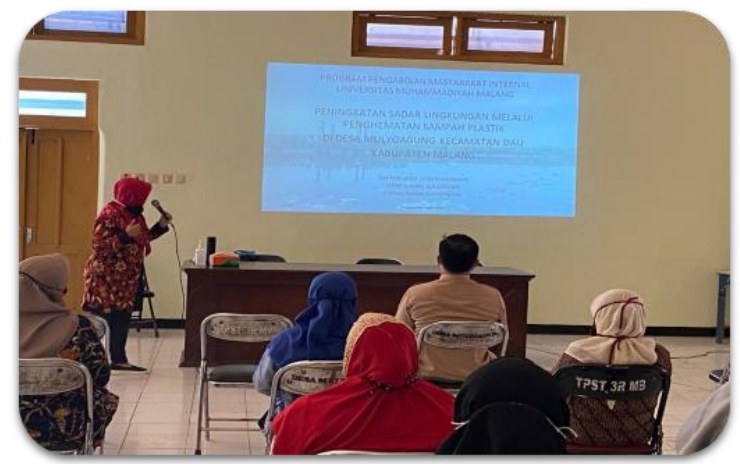

Gambar 3. Kegiatan edukasi dan penyuluhan bahaya sampah plastik

2. Pembuatan Baliho dan Poster Berisi Himbauan Pengurangan Penggunaan Produk Berbahan Baku Plastik Sebagai Bentuk Kampanye Untuk Hemat Sampah Plastik

Pemasangan baliho dan poster di tempat-tempat strategis seperti di depan kantor Desa Mulyoagung yang banyak dikunjungi masyarakat umum sebagai bentuk kampanye untuk menghemat sampah plastik di kawasan Desa Mulyoagung, Kecamatan Dau, Kabupaten Malang. Harapan dari 
pemasangan Baliho di tempat yang strategis adalah dapat dilihat oleh masyarakat setiap saat, sehingga secara tidak langsung masyarakat selalu diingatkan tentang bahaya sampah plastik sehingga akan memunculkan perubahan perilaku masyarakat yang bijak dalam mengelola sampah.

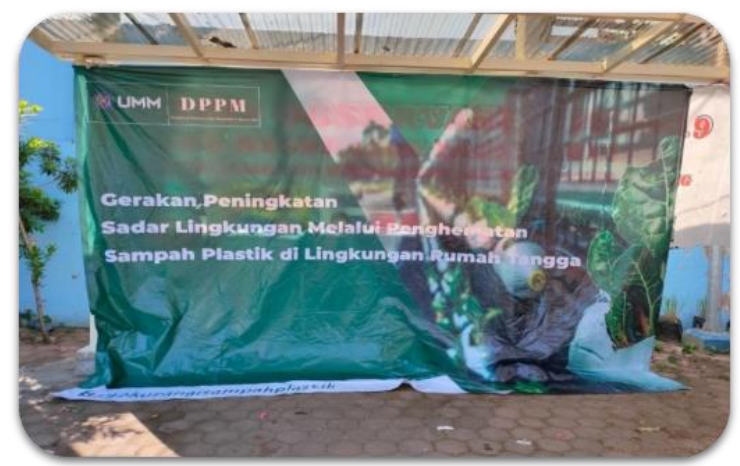

Gambar 4. Pemasangan baliho di depan kantor desa Mulyoagu

\section{Pemberian Tumbler Bagi Masyarakat dan Kepala Desa Beserta Perangkat Desa di Desa Mulyoagung Kecamatan Dau Kabupaten Malang}

Tumbler dibagikan kepada perangkat desa dan masyarakat sekitar sebagai substitusi penggunaan air mineral kemasan botol plastik. Pemakaian tumbler di kalangan perangkat Desa merupakan salah satu bentuk kepedulian mereka terhadap gerakan hemat sampah plastik. Kebiasaan membawa tumbler ke kantor bagi mereka merupakan kebiasaan baru yang masih harus dingatkan terus menerus. Saling mengingatkan antar sesama karyawan merupakan cara yang baik agar komitmen mereka terhadap gerakan hemat sampah plastik dapat berjalan dengan baik. Jika dari sisi pimpinan dan perangkat desa telah terbiasa menggunakan tumbler, maka dapat dijadikan contoh bagi masyarakat supaya diterapkan pada kehidupan sehari-hari.



Gambar 5. Pembagian tumbler secara simbolis kepada Kepala Desa Mulyoagung 


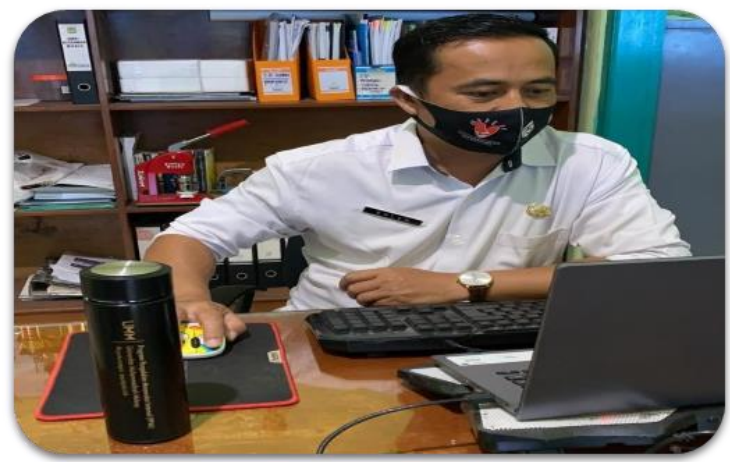

Gambar 6. Penggunaan tumbler di lingkungan kantor desa

\section{KESIMPULAN}

Setelah dilakukan pengabdian dalam bentuk pendampingan peningkatan sadar lingkungan melalui penghematan sampah plastik di Desa Mulyoagung Kecamatan Dau Kabupaten Malang dapat di simpulkan bahwa terjadi peningkatan sadar lingkungan di masyarakat sekitar. Langkah awal yang dilakukan tim pengabdi adalah memberikan informasi kepada masyarakat dalam bentuk penyuluhan tentang bahaya sampah plastik dengan cara ceramah dan diskusi. Peserta penyuluhan terdiri dari Kepala Desa beserta perangkatnya dan ibu-ibu yang tergabung dalam PKK Desa yang sangat antusias serta aktif dalam sesi Tanya jawab. Seusai kegiatan penyuluhan, para peserta diberi tumbler sebagai salah bentuk langkah nyata untuk mengurangi penggunaan botol minuman plastik.

Dalam rangka memperkuat dan mendukung gerakan hemat sampah di lingkungan Desa Mulyoagung, maka dilakukan pemasangan baliho di depan kantor desa dengan tujuan agar lebih efektif jika informasi tersebut dapat dibaca setiap saat sehingga muncul perubahan perilaku masyarakat yang bijak dalam mengelola sampah khususnya sampah plastik. Baliho dipasang di tempattempat strategis yang banyak dikunjungi masyarakat umum sebagai bentuk kampanye untuk menghemat sampah plastik di kawasan Desa Mulyoagung.

Sebagai tindak lanjut dari kegiatan pengabdian ini adalah tim pengabdi merencanakan untuk mengadakan kegiatan pengabdian dimasa yang akan datang dengan topik yang berkaiatan dengan isu-isu lingkungan. Sebagai rencana tim pengabdi membuat program gerakan pengolahan limbah rumah tangga melalui kegiatan pembuatan eco enzyme.

\section{DAFTAR RUJUKAN}

Borealis. (2018). NOVA Chemicals Takes Action to Prevent Plastic Debris from Reaching the Ocean. Borealis Keep Discovering.

Desfandi, M. (2015). Mewujudkan masyarakat berkarakter peduli lingkungan melalui program adiwiyata. 2(1), 31-37. https://doi.org/10.15408/sd.v2i1.1661

Dobrovszky, K. (2018). Temperature Dependent Separation of Immiscible Polymer Blend in A Melted State. Waste Management, 77, 364-372. 
https://doi.org/10.1016/j.wasman.2018.04.021

Garofalo, E., Di Maio, L., Scarfato, P., Di Gregorio, F., \& Incarnato, L. (2018). Reactive Compatibilization and Melt Compounding with Nanosilicates of Post-Consumer Flexible Plastic Packagings. Polymer Degradation and Stability, 152 , 52-63. https://doi.org/10.1016/j.polymdegradstab.2018.03.019

Hendiarti, N. (2018). Combating Marine Plastic Debris in Indonesia.

Karmanah, Karmanah, Wibaningwati, D. B., \& Rusli, A. R. (2016). IbM Pengelolaan Sampah Rumah Tangga Sebagai Upaya Menciptakan Kampung Pro Iklim (PROKLIM). Research Report, 480-487.

Lathif, N. (2019). Kewenangan Penyelenggaraan Program Pengurangan Kantong Plastik Di Wilayah Kota Bogor. Jurnal Gagasan Hukum, 1(1), 41-62. https://journal.unilak.ac.id/index.php/gh/article/view/2902

Lupiyanto, R. (2020). Dapatkah Indonesia Bebas dari Kantong Plastik? Mongabay Situs Berita Lingkungan.

Oktavia, H. (2019). dr. Gamal, Arek Malang Inisiator Klinik Asuransi Sampah Hingga Aplikasi Layanan Kesehatan. Rri.Co.ld.

Purwaningrum, P. (2016). Upaya Mengurangi Timbulan Sampah Plastik Di Lingkungan. Indonesian Journal of Urban and Environmental Technology, $8(2)$,

141.

https://doi.org/10.25105/urbanenvirotech.v8i2.1421

Purwoko. (2012). Ideally, the amount of waste entering the Piyungan landfill site can be reduced from its source regardless of the methods (composting, recycling, etc.) (Sarkar et al., 2016; Colón et al., 2010). If the reductions on its source run well, then the amount of. Kajian Ekonomi Dan Keuangan, 16(2),

77-105. https://doi.org/https://doi.org/10.31685/kek.v16i2.44

Restuningdiah, N., Nagari, P. M., Jati, F. D., \& Azzardina, A. (2021). Literasi bank sampah dan asuransi sampah sebagai upaya peningkatan kesejahteraan masyarakat. Jurnal Inovasi Hasil Pengabdian Masyarakat (JIPEMAS), $\quad 4(1), \quad 144-152$. https://doi.org/10.33474/jipemas.v4i1.9140

Riswan, Sunoko, H. R., \& Hadiyanto, A. (2015). Pengelolaan Sampah Rumah Tangga di Kecamatan Daha Selatan. Jurnal Ilmu Lingkungan, 9(1), 3139. https://doi.org/https://doi.org/10.14710/jil.9.1.31-38

Sari, M., Lestari, S. U., \& Awal, R. (2018). Peningkatan Ketrampilan Mahasiswa Dalam Pengelolaan Sampah Organik Untuk Mewujudkan Green Campus Di Universitas Lancang Kuning. Dinamisia : Jurnal Pengabdian Kepada Masyarakat, 2(2), 193-196. https://doi.org/10.31849/dinamisia.v2i2.1392

Septiani, B. A., Arianie, D. M., Risman, V. F. A. A., Handayani, W., \& Kawuryan, I. S. S. (2019). Pengolahan Sampah Plastik di Salatiga: Praktik, dan tantangan. Jurnal IImu Lingkungan, 17(1), 90-99. https://doi.org/10.14710/jil.17.1.90-99

Sudibyo, H., Pradana, Y. S., Budiman, A., \& Budhijanto, W. (2017). Municipal Solid Waste Management in Indonesia - A Study about Selection of 
Proper Solid Waste Reduction Method in D.I. Yogyakarta Province. Energy Procedia, 143 , 494-499. https://doi.org/10.1016/j.egypro.2017.12.716

Thompson, R. C., Moore, C. J., Saal, F. S. V., \& Swan, S. H. (2009). Plastics, the environment and human health: Current consensus and future trends. Philosophical Transactions of the Royal Society B: Biological Sciences, 364(1526), 2153-2166. https://doi.org/10.1098/rstb.2009.0053

TPST Mulyoagung Bersatu. (2020). Laporan Tahunan TPST.

Utomo, Y. W. (2016). Bandung Larang Penggunaan "Styrofoam" mulai 1 November 2016. Kompas.Com. 